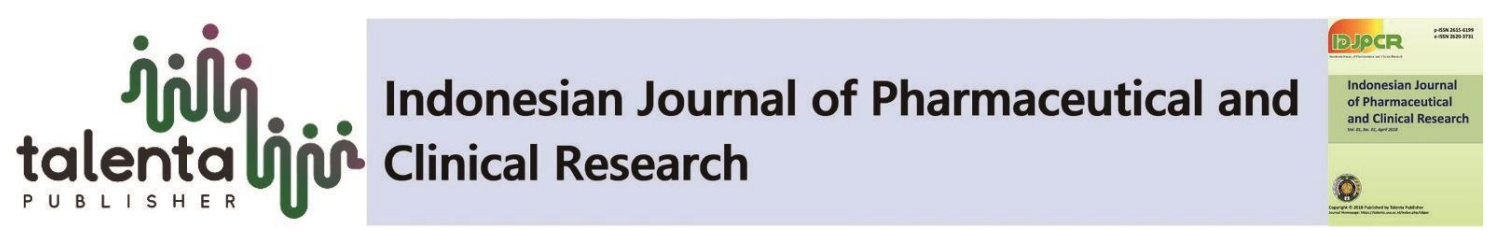

\title{
Antibacterial Activity of Ethyl Acetate Fraction of Passion Fruit Peel (Passiflora edulis Sims) on Staphylococcus Aureus and Escherichia Coli
}

\author{
Sony Eka Nugraha*, Suryadi Achmad and Erly Sitompul \\ Department of Pharmaceutical Biology, Faculty of Pharmacy, Universitas Sumatera Utara, Medan \\ 20155, Indonesia
}

\begin{abstract}
North Sumatera is one of the central areas of purple passion fruit production in Indonesia. Processing passion fruit into beverage products (passion fruit juice) produces peel has not been utilized. The use of passion fruit skin needs to be studied so that it can be useful as a raw material for antibacterial drug preparations. The aim of this study was to determine the phytochemical constituent screening and antibacterial activity of ethyl acetate fraction of purple passion fruit peel against Staphylococcus aureus and Escherichia coli. Simplicia and ethyl acetate fraction were determinated its phytochemical properties. The extraction process by percolation method using ethanol $96 \%$ and continue to fractionation process by liquid liquid extraction method using n-hexane and ethyl acetate. The antibacterial activity were tested against Staphylococcus aureus and Escherichia coli using agar diffusion method with paper discs. The result showed that the simplicia characteristic of passion fruit peel were water content of $8.64 \%$, water soluble extract of $31.69 \%$, ethanol soluble extract of $13.02 \%$, ash total of $7.89 \%$, and insoluble ash in acid of $0.816 \%$. The phytochemical screening simplicia and ethyl acetate fraction showed the presence of flavonoids, glycosides, saponins and tannins. The antibacterial activity test showed that the ethyl acetate fraction has an effective inhibition at the concentration of 100 $\mathrm{mg} / \mathrm{ml}$ against Staphylococcus aureus and Escherichia coli, it showed dose dependent manner. The ethyl acetate fraction of passion fruit peel (Passiflora edulis Sims) has an antibacterial activity on Staphylococcus aureus and Escherichia coli
\end{abstract}

Keywords: Passiflora edulis Sims, ethyl acetate fraction, antibacterial, Staphylococcus aureus and Escherichia coli

\begin{abstract}
Abstrak. Sumatera Utara adalah salah satu daerah pusat produksi buah markisa ungu di Indonesia. Pengolahan buah markisa menjadi produk minuman menghasilkan limbah kulit yang belum dimanfaatkan. Manfaat kulit buah markisa dikembangkan sehingga dapat bermanfaat salah satunya iaitu sebagai antibakteri. Tujuan dari penelitian ini adalah untuk menentukan kandumngan fitokimia dan aktivitas antibakteri fraksi etil asetat kulit buah markisa ungu terhadap Staphylococcus aureus dan Escherichia coli. Simplisia dan fraksi etil asetat ditentukan sifat fitokimia. Proses ekstraksi dengan metode perkolasi menggunakan etanol 96\% dan berlanjut ke proses fraksinasi dengan metode ekstraksi cair menggunakan n-heksan dan etil asetat. Aktivitas antibakteri diuji terhadap Staphylococcus aureus dan Escherichia coli menggunakan metode difusi agar dengan cakram kertas. Skrining fitokimia simplisia dan fraksi etil asetat menunjukkan adanya flavonoid, glikosida, saponin, dan tanin. Uji aktivitas antibakteri menunjukkan bahwa fraksi etil asetat memiliki penghambatan

yang
\end{abstract}

\footnotetext{
*Corresponding author at: Department of Pharmaceutical Biology, Faculty of Pharmacy, Universitas Sumatera

Utara, Padang Bulan, Medan 20155, Indonesia

E-mail address: sonyekanugraha@usu.ac.id
} 
efektif pada konsentrasi $100 \mathrm{mg} / \mathrm{ml}$ terhadap Staphylococcus aureus dan Escherichia coli. Fraksi etil asetat kulit buah markisa (Passiflora edulis Sims) memiliki aktivitas antibakteri pada Staphylococcus aureus dan Escherichia coli.

Kata kunci: Passiflora edulis Sims, Fraksi etil asetat, antibakteri, Staphylococcus aureus and Escherichia coli

Received 16 March 2019 | Revised 22 April 2019| Accepted 25 April 2019.

\section{Introduction}

Purple passion fruit (Passiflora edulis Sims) contains some phytochemical constituent that has potential effect as antibacterial. Leaves of purple passion fruit contain some secondary metabolite such as glycosides, tannins, flavonoids, saponins and alkaloids, where as the stems contain of glycosides, flavonoids, saponins and alkaloids, while fruits contain glycosides, tannins, flavonoids and alkaloids [1]. The lastest study reported that methanol extract of purple passion fruit leaves had antibacterial activity against several bacteria such as Staphylococcus aureus, Staphylococcus faecalis, Bacillus subtilis, Escherichia coli, Proteus vulgaris and Salmonella typhi [2].

Purple passion fruit is planted in tropical highlands and subtropical areas around of 700 to $2000 \mathrm{~m}$ above sea level with temperatures of 18 to $25^{\circ} \mathrm{C}$. The central production of passion fruit in Indonesia was North Sumatera province. The passion fruit was processing into beverage product that produced passion fruit peel waste. The phytochemical constituent of passion fruit peel has potential effect as a sources of medicine which is need to be examined such as its antibacterial effect. It is necessary to determine antibacterial activity of ethyl acetate fraction of purple passion fruit peel on Staphylococcus aureus dan Escherichia coli.

\section{Materials and Methods}

The materials that used in this study were purple passion fruit peel, nutrient agar, nutrient broth, distilled water, ethanol, ethyl acetate, Staphylococcus aureus ATCC 25923 and Escherichia coli ATCC 25922. Fresh fruit of Passiflora edulis Sims were collected in Central Market of Medan, Indonesia. The sample was identified at Indonesian Institute of Science, Research Center of Biology, Bogor, Indonesia. Authentification number 440/IPH.1.01/lf.07/IV/2015

\subsection{Extraction}

An amount of $300 \mathrm{~g}$ dried material plant samples were crushed in a blender, then macerated in ethanol $96 \%$ for 3 hours then moved to perlocator tube. Percolation process was stopped if the last $500 \mathrm{mg}$ of solvent were evaporated, and leaving no residuals. The solvent was evaporated at low pressure with a temperature of not more than $40{ }^{\circ} \mathrm{C}$ using a Rotary evaporator. The crude 
extract were continued to fractionation process by liquid liquid extraction method using nhexane and ethyl acetate

\subsection{Phytochemical Screening}

Phytochemical simplicia and ethyl acetate fraction of passion fruit peel includes examining the chemical secondary metabolites of alkaloids, flavonoids, glycosides, tannins, saponins, triterpenoids, and steroids [3-5].

\subsection{Antibacterial Activityof ethyl acetate fraction of purple passion fruit}

Bacterial colonies were taken from the culture stock with a sterile ose needle then suspended in a test tube containing $10 \mathrm{ml}$ of broth nutrient media, then measured turbidity of the solution at a wavelength of $580 \mathrm{~nm}$ until a $25 \%$ transmittance was obtained which was equivalent to 106 CFU (Colony Forming Units) [6].

As much as $1 \mathrm{~g}$ crude extract of ethyl acetate fraction of passion fruit peel was carefully weighed on an analytical balance. Extract was dissolved in $2 \mathrm{ml}$ DMSO solvent in a vial and obtained extract concentration of $500 \mathrm{mg} / \mathrm{ml}$. The solvent was diluted to several concentrations of $400 \mathrm{mg} / \mathrm{ml}, 300 \mathrm{mg} / \mathrm{ml}, 200 \mathrm{mg} / \mathrm{ml}, 100 \mathrm{mg} / \mathrm{ml}, 75 \mathrm{mg} / \mathrm{ml}, 50 \mathrm{mg} / \mathrm{ml}, 25 \mathrm{mg} / \mathrm{ml}$, $12.5 \mathrm{mg} / \mathrm{ml}$ and $6.25 \mathrm{mg} / \mathrm{ml}$. The bacteria inoculum as many as $0.1 \mathrm{ml}$ is put into a petri dish, then added $20 \mathrm{ml}$ of nutrient agar wait until the temperature reaches $45^{\circ} \mathrm{C}$, homogenized and left it until the media become a solid form. Furthermore, paper discs (diameter of $6 \mathrm{~mm}$ ) are immersed in extract solution on various concentrations, dried and placed on the surface of the agar media. Media was incubated at $36-37^{\circ} \mathrm{C}$ for $18-24$ hours. The diameter of the inhibitory area around the paper disc is measured using a calipse. The test was carried out 3 times [6].

\section{Result and Discussion}

The qualitative test of phytochemical properties on simplicia, ethanol extract and ethyl acetate fraction purple passion fruit shows in table 1.

Table 1. Phytochemical screening of simplicia,ethanol extract and ethyl acetate fraction of purple passion fruit

\begin{tabular}{ccccc}
\hline No. & Phytochemical properties & Simplicia & Ethanol extract & Ethyl acetate fraction \\
\hline 1. & Alkaloids & - & - & - \\
2. & Flavonoids & + & + & + \\
3. & Glycosides & + & + & + \\
4. & Anthraquinone glycosides & - & - & - \\
5. & Saponin & + & + & + \\
6. & Tanin & + & + & + \\
7. & Steroids/Triterpenoids & + & + & - \\
\hline
\end{tabular}


Table 1 shows that the simplicia and ethanol extract purple passion fruit have several compound such as flavonoids, glycosides, anthraquinone glycosides, saponin, tanin and steroids/triterpenoids. Ethyl acetate fraction contain of flavonoids, glycosides, anthraquinone glycosides, saponin and tanin. Flavonoids, tanin, saponins and steroids / triterpenoids are phytochemical compounds that have potential effect as antibacterial and antiviral agents.

The results of antibacterial test of ethyl acetate fraction on Staphylococcus aureus and Escherichia coli can be seen in the table 2.

Table 2. Diameter of Inhibiting area on Staphylococcus aureus and Escherichia coli

\begin{tabular}{llllllllll}
\hline & & \multicolumn{9}{c}{ Diameter of Inhibition area (mm) } \\
\cline { 3 - 10 } No. & $\begin{array}{c}\text { Concentration } \\
(\mathrm{mg} / \mathrm{ml})\end{array}$ & \multicolumn{9}{c}{ Staphylococcus aureus } & \multicolumn{5}{c}{ Escherichia coli } \\
\cline { 3 - 10 } & & D1 & D2 & D3 & Mean & D1 & D2 & D3 & Mean \\
1. & 500 & 20.7 & 20.4 & 20.3 & 20.46 & 20.2 & 20.5 & 20.6 & 20.43 \\
2. & 400 & 19.3 & 19.2 & 19.4 & 19.3 & 19.4 & 19.7 & 19.5 & 19.53 \\
3. & 300 & 18.2 & 18.2 & 18.3 & 18.23 & 18.3 & 18.6 & 18.4 & 18.43 \\
4. & 200 & 16.3 & 16.4 & 16.5 & 16.4 & 16.7 & 17.1 & 16.8 & 16.86 \\
5. & 100 & 14.2 & 14.3 & 14.1 & 14.2 & 14.2 & 14.3 & 14.2 & 14.23 \\
6. & 75 & 12.5 & 12.1 & 12.4 & 12.33 & 12.5 & 12.4 & 12.2 & 12.36 \\
7. & 50 & 11.6 & 11.3 & 11.4 & 11.43 & 10.9 & 11.2 & 11.0 & 11.03 \\
8. & 25 & 10.4 & 10.2 & 10.3 & 10.3 & 9.6 & 9.5 & 9.4 & 9.5 \\
9. & 12.5 & 7.5 & 7.2 & 7.3 & 7.33 & 7.2 & 7.4 & 7.2 & 7.26 \\
10 & 6.25 & - & - & & - & - & - & & - \\
11. & Blank & - & - & - & - & - & - & - & - \\
\hline
\end{tabular}

where:

$\mathrm{D}:$ diameter $(\mathrm{mm})$

The concentration of extract which fulfill the requirements of Indonesian Pharmacopoeia was the concentration of extracts with an effective inhibition area of approximately 14-16 mm [6]. The results of antibacterial activity of ethyl acetate fraction on Staphylococcus aureus and Escherichia coli showed an effective inhibition at the concentration of $100 \mathrm{mg} / \mathrm{ml}$ with an effective inhibition diameters were $14.2 \mathrm{~mm}$ and $14.23 \mathrm{~mm}$ respectively. Minimum inhibition concentration of ethyl acetate fraction against Staphylococcus aureus and Escherichia coli at the concentration of $12.5 \mathrm{mg} / \mathrm{ml}$ with inhibitory diameter of $7.33 \mathrm{~mm}$ and $7.26 \mathrm{~mm}$ respectively. Ethyl acetate fraction of passion fruit peel has an effect in inhibiting the growth of Staphylococcus aureus and Escherichia coli bacteria due to its phytochemical properties that has strong antibacterial activity, namely flavonoids, tannins and saponins.

Tannins are phenol compounds that are widely distributed in vascular plants. Phenol compounds and their derivatives were one of the antibacterials that works by disrupting the function of the cytoplasmic membrane, low concentrations of phenol compound could damage the cytoplasmic membrane which causes leaking of metabolites that is important in bacterial enzyme system, while at high concentrations, it could damage the cytoplasmic membrane and proteins of cell [5, 
7]. Saponins are used as antimicrobials in recent years. The mechanism of action of saponins as antibacterials is to reduce surface tension resulting in increased permeability or leakage of cells, it resulting dicharge of intracellular compounds [8]. Steroids and triterpenoid aslo has antibacterial activities, some studies reported antibacterial activitiy of steroid and triterpenoid againts several bacteria [9-11].

The results showed that the Staphylococcus aureus bacteria had a greater inhibitory zone compared to Escherichia coli bacteria in various concentrations of the test solution. The difference was occurs because the two test bacteria species have different composition and cell wall structure. Gram-positive bacteria more susceptible to chemical compounds than gramnegative. The cell wall structure of gram-positive bacteria is simpler, it has single-layered with a low lipid content (1-4\%) making it easier for bioactive ingredients to enter the cell. The structure of cell wall of the gram-negative bacterial is more complex, it has three-layered consisting of the outer layer of lipoprotein, the middle layer of lipopolysaccharide which acts as a barrier to antibacterial bioactive material, and an inner layer of peptidoglycan with high lipid content (11-12\%) [12-14].

\section{Conclusion}

Antibacterial activity of ethyl acetate fraction of purple passion fruit on Staphylococcus aureus and Escherichia coli showed an effective inhibition at the concentration of $100 \mathrm{mg} / \mathrm{ml}$, it is showed dose dependent manner.

\section{Acknowledgment}

The authors thanks to Faculty of Pharmacy, University of Sumatera Utara for supporting this research.

\section{REFERENCES}

[1] B.O. Akanbi, O.D. Bodunrin, S.Olayanju, "Phytochemical screening and antibacterial activity of Passiflora edulis", Researcher, vol.3, no.5, pp.9-12. 2001.

[2] J. M. Nicolls, J. Birner, and P. Forsell, "Passicol, an Antibacterial and Antifungal Agent Produced by Passiflora Plant Species: Qualitative and Quantitative Range of Activity," Antimicrobial Agents and Chemotherapy, vol. 3, no. 1, pp. 110-117, Jan. 1973.

[3] Ministery of Health of Indonesia, Materia Medika, 6th Edition. Jakarta, p. 297-307. 1995.

[4] N.R. Farnsworth, "Biologycal and phytochemical screening of plants". J Pharm Sci, vol. 55, no.3, pp. 225-76. 1996.

[5] J.B. Harbone, Phytochemical Method, ITB. p. 49.1987

[6] Directorate General of Drug And Food Control, Indonesian Pharmacopoeia, Edition IV, Ministry of Health of Indonesia,p. 891 - 898, 1035.1995

[7] M. J. R. Vaquero, M. R. Alberto, and M. C. M. de Nadra, "Antibacterial effect of phenolic compounds from different wines," Food Control, vol. 18, no. 2, pp. 93-101, Feb. 2007. 
[8] P. Mandal, S. P. Sinha Babu, and N. C. Mandal, "Antimicrobial activity of saponins from Acacia auriculiformis," Fitoterapia, vol. 76, no. 5, pp. 462-465, Jul. 2005

[9] A. Nick, A. D. Wright, O. Sticher, and T. Rali, "Antibacterial Triterpenoid Acids from Dillenia papuana," Journal of Natural Products, vol. 57, no. 9, pp. 1245-1250, Sep. 1994.

[10] X.T. Liu, A. Winkler, W. Schwan, T. Volk, M. Rott, and A. Monte, "Antibacterial Compounds from Mushrooms II: Lanostane Triterpenoids and an Ergostane Steroid with Activity AgainstBacillus cereusIsolated fromFomitopsis pinicola," Planta Medica, vol. 76, no. 05, pp. 464-466, Oct. 2009.

[11] S.-G. Liao, L.-J. Zhang, F. Sun, J.-J. Zhang, A.-Y. Chen, Y.-Y. Lan, Y.-J. Li, A.-M. Wang, X. He, Y. Xiong, L. Dong, X.-J. Chen, Y.-T. Li, L. Zuo, and Y.-L. Wang, "Antibacterial and anti-inflammatory effects of extracts and fractions from Polygonum capitatum," Journal of Ethnopharmacology, vol. 134, no. 3, pp. 1006-1009, Apr. 2011.

[12] J. L. Kadurugamuwa and T. J. Beveridge, "Membrane vesicles derived from Pseudomonas aeruginosa and Shigella flexneri can be integrated into the surfaces of other Gram-negative bacteria," Microbiology, vol. 145, no. 8, pp. 2051-2060, Aug. 1999.

[13] A. M. Fayaz, K. Balaji, M. Girilal, R. Yadav, P. T. Kalaichelvan, and R. Venketesan, "Biogenic synthesis of silver nanoparticles and their synergistic effect with antibiotics: a study against gram-positive and gram-negative bacteria," Nanomedicine: Nanotechnology, Biology and Medicine, vol. 6, no. 1, pp. 103-109, Feb. 2010.

[14] M. R. J. Salton, "The nature of the cell walls of some gram-positive and gram-negative bacteria," Biochimica et Biophysica Acta, vol. 9, pp. 334-335, Jan. 1952. 